\title{
DESIGN FOR RECYCLING - THINKING OF THE END AT THE BEGINNING
}

Dušan Gruden ${ }^{1}$

UDC: 621.01:502.174.1

DOI: $10.24874 / \mathrm{mvm} .2017 .43 .03 .03$

\begin{abstract}
Regulations of the European Union are demanding that re-use of materials should be taken into account already in the design phase of new vehicles and to provide instructions about exploitation of the old cars. When engineering a car, every part of the vehicle is analysed in terms of ecological criteria: "the possibility of re-use of materials", "convenience for recycling" and "critical materials". The primary principle of "Design for recycling" is using a closed circuit of materials. Recycled material must fully correspond to the new material in all its properties. Analysis of different materials shows that with the increasing application of recycled materials substantial savings in energy consumption and raw materials can be achieved. Selection of plastic materials plays a very important role in the engineering of the car taking into account the recycling. Labelling the plastic allows its clean sorting and re-use. In addition, an important criterion is easy disassembly of the parts to be used again. Car producers are obliged to prepare manuals for disassembling for each vehicle.
\end{abstract}

KEY WORDS: recycling, design, selection of materials, energy savings, disassembling, LCA

\section{KALIBRACIJA UREĐAJA ZA KONVERGENCIJU KORIŠĆENJEM FOTOGRAMETRIJE}

REZIME: Propisi Evropske Unije zahtevaju da se ponovna upotreba materijala treba uzeti u obzir u fazi projektovanja novih vozila i da se pruže upustva ekspolatacije starih votila. Prilikom projektovanja automobila, svaki deo vozila se analizira u smislu ekološkog kriterijuma: "mogućnost ponovnog korišćenja materijala", "pogodnosti za reciklažu" i "kritičnih materijala". Primarni princip "Dizajn za reciklažu" koristi zatvoreni krug materijala. Reciklirani materijal mora u potpunosti odgovarati novom materijalu po svim svojstvima. Analiza različitih materijala pokazuje da se uz sve veću primenu recikliranih materijala može ostvariti značajna ušteda u potrošnji energije i sirovina. Izbor plastičnih materijala igra veoma važnu ulogu u inženjeringu automobila uzimajući u obzir recikliranje. Označavanje plastike omogućava njeno čisto sortiranje i ponovnu upotrebu. Pored toga, važan kriterijum je jednostavna demontaža delova koji će se ponovo koristiti. Proizvođači automobila su obavezni da pripreme priručnike za demontažu za svako vozilo.

KLJUČNE REČI: kalibracija, etaloniranje, podešavanje točkova, merilo, fotogrametrija

${ }^{1}$ Received: June 2017, Accepted August 2017, Available on line December 2017 
Intentionally blank 


\title{
DESIGN FOR RECYCLING - THINKING OF THE END AT THE BEGINNING
}

\author{
Dušsan Gruden ${ }^{1}$
}

\section{INTRODUCTION}

Average life of cars in the European Union amounts between 12 to 14 years. After this service life, a question arises what to do with an old car? What to do with a car that is frequently called "automotive rubbish"? Around 20 to 22 million cars in the world and around 7 to 9 million cars in the European Union reach this status every year.

Efforts of modern society to reduce a negative effect of human activity on natural environment do not leave behind the end-of-use cars ("End of Life Vehicles", ELV). In October 2000, a regulation regarding end of life vehicles was issued in the European Union, which has become obligatory for all member states since 2002 [2]. Provisions of this regulation demand that reuse of the used materials should be taken into account already at the design stage of the new vehicles. They also contain instructions on exploitation of the old cars.

For all new cars let into traffic after January 1st, 2006, it must be proved that $85 \%$ of average vehicle weight can be recycled or re-used in other way, Figure 1.

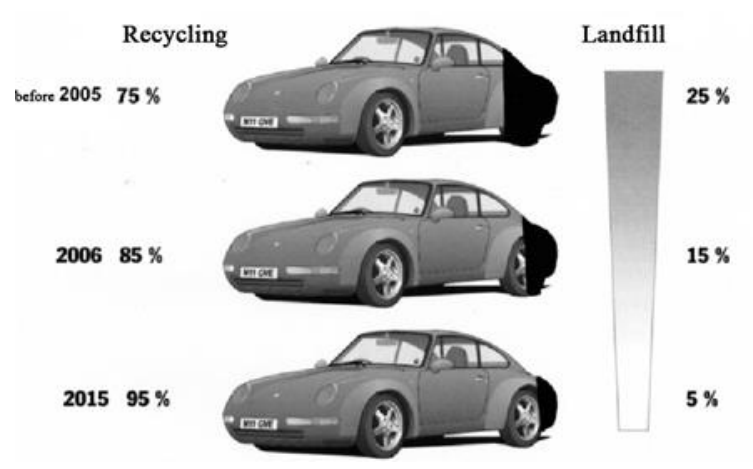

Figure 1. Recycling of the old cars

Only $5 \%$ of it may be energetically (thermally) re-used, while $15 \%$ of vehicle weight may be deposited at landfills. Since January 2015, a re-use quota has been raised to $95 \%, 10 \%$ of which may be energetically re-used, while $5 \%$ may be deposited at landfills.

${ }^{1}$ Dušan Gruden, Prof. Dr. techn., Dr. h. c Honorary Professor TU Viena, Aspergstr.10, D-71254 Ditzingen, Germany, gruden@yudit.de 
These goals can be achieved only if demands regarding preservation of the human environment and especially on vehicle recycling are already defined in the phase of definition and car design, alongside with technical and economic parameters.

\section{LIFETIME OF A VEHICLE}

After the decision on building a new vehicle is reached, analyses and prognoses on future market development and economic, social and ecological developments during the planned time for production of the given model are conducted.

In long-life products like cars, the main challenge for designers is that decisions on car recycling must be made in the phase of definition and generation of the vehicle, although the act on recycling would be valid after 15 to 25 years, when the recycling technology might be altogether different than assumed at the vehicle design phase [3].

It takes 3 to 4 years to develop a new engine and a new vehicle, Figure 2. This means that, at least 3 years before the beginning of production, the legal regulations that would be set before the car at the time it is let into traffic must be known.

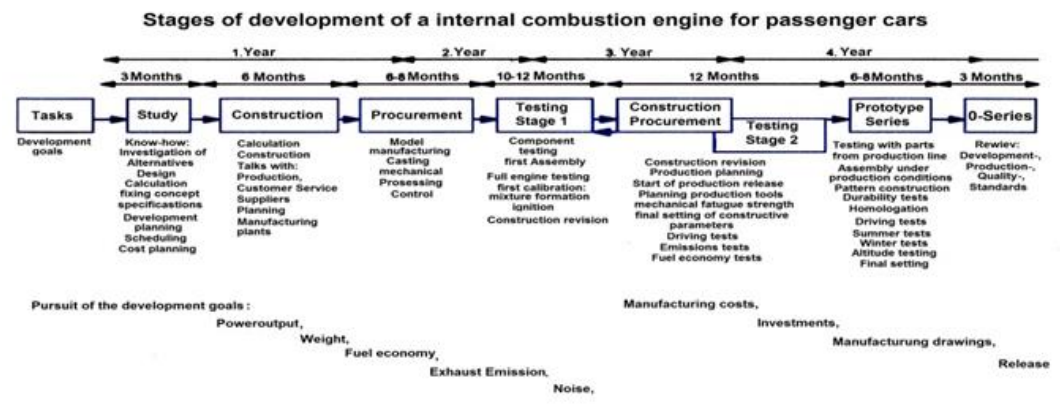

Figure 2. Phases of IC engine development (Source: Ampferer)

Production of one model lasts 4 to 8 years, while its average traffic life is 12 to 14 years, Figure 3. 




Objectivs: better understanding the impact and ELV costs at the beginning of the overall project

Figure 3. The duration time of one model of vehicle (Source: VW)

Around 20 to 25 years pass, from the concept design, through beginning of production to car recycling. The automotive producers must be active during all that time. In addition to market development, they must take care also on technological development and development of legislative during that period.

The automotive producers make only $30 \%$ to $40 \%$ share of car value. The greatest share of car value (60\% to $70 \%$ ) is made by suppliers industry, Figure 4 .

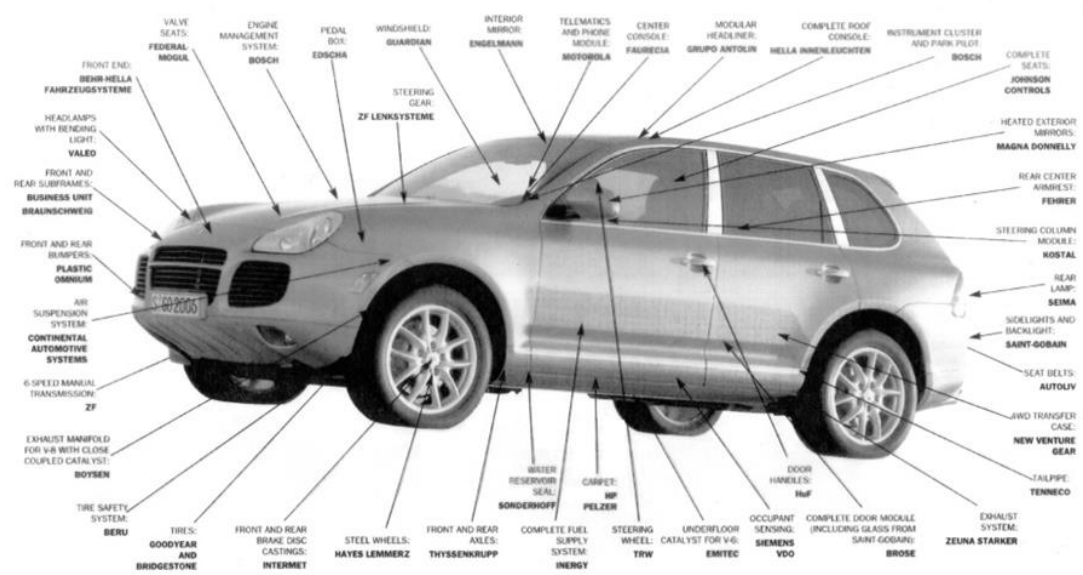

Figure 4. Suppliers for Porsche Cayenne

That is why the suppliers industry bears a large share of responsibility in the achievement of the objectives of the automotive industry, including requirements in terms of ecology and especially recycling the cars. 


\section{DESIGN FOR RECYCLING}

Car manufacturers are required to construct their vehicles in accordance with the legal regulations in terms of safety, fuel economy, exhaust and noise emissions, and in terms of economic feasibility, production costs, as well as many other features, Figure 5.

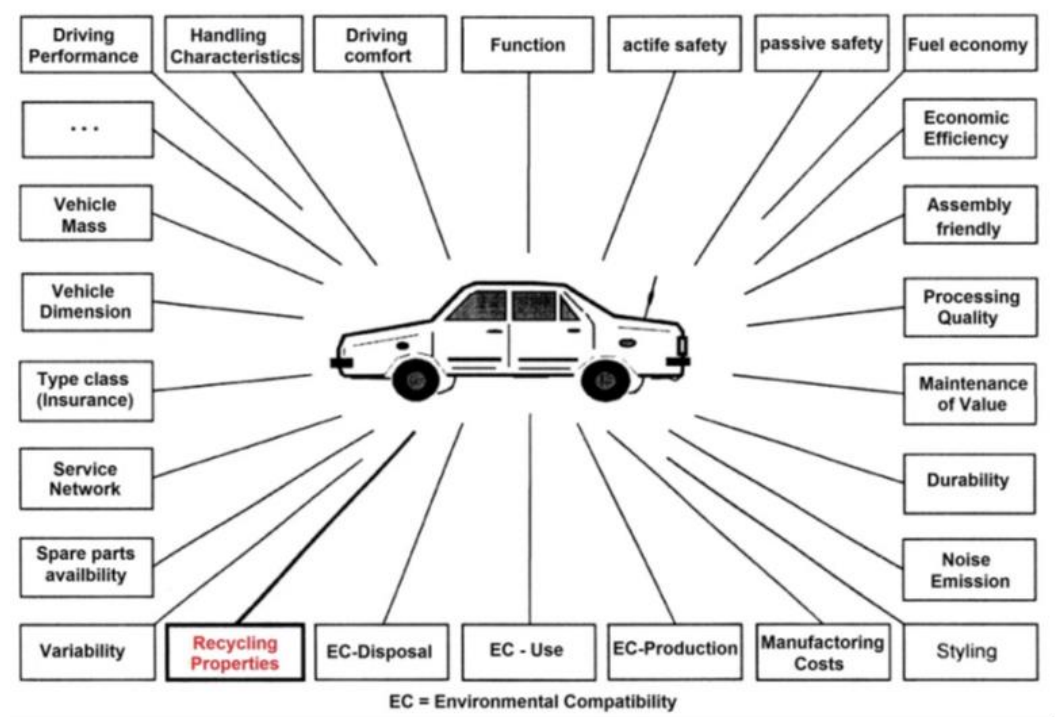

Figure 5. Requirements in car design (Source: $B M W$ )

Optimization of all requests that are put in front of car development, leads to decisions on the selection and implementation of certain materials in the design of the vehicle $[4,5]$.

Responsibility of the designer is not completed by the fulfilment of the requirements in terms of functionality, production processes and cost-efficiency of products. It extends to a "comprehensive product liability" during the entire lifetime of the product, until the end of its use, or its re-use in the process of recycling or ecological removal from the traffic.

During design, every part of the vehicle has to be tested in terms of environmental criteria: "the possibility of re-use of the material", "convenience for recycling" and "critical materials", together with the testing concerning the technical and economic benefits.

Most manufacturers have their own, specific regulations for recycling, which must be taken into account in the design of the vehicle. These regulations are obligatory for designers from both the automotive industry and the suppliers industry. In this context, it is important to point out the "International Material Data System" (IMDS), which was developed in cooperation between almost all world automotive manufacturers and their suppliers industries [6]. The IMDS's goal is a precise description of the chemical composition of all parts of the car, because, in order to fulfil the request of the European regulation on recycling of $95 \%$ of the vehicle weight, the chemical composition of the product must be known. 
The focus of vehicle design with regard to recycling is made of the selection of materials and technique for bonding parts and assemblies.

The following recommendations are given to the designers for the realization of "recyclable design":

- As small as possible application of different materials, in order to be more easily identified and sorted for recycling.

- Preferably, apply not only recycled materials, but also materials containing recyclates.

- Problematic substances should be limited to the required minimum. Avoid the substances that can be dangerous for production or for recycling.

- The number of different bindings and applied adhesives should be reduced to the essential minimum.

- Select the bindings that are eventually easily disassembled at the end of the use of car.

- $\quad$ Plastic materials should be marked according to ISO norms.

\section{SELECTION OF MATERIALS}

Recycling of cars is closely related to the number and type of applied materials and simplicity with which materials can be identified and separated.

Number of applied materials should preferably be as small as possible. In ideal case, all parts of an assembly should be of the same material, or from materials that are chemically related.

The primary principle of "design for recycling" is to organize and use the material recirculation. Recycled material must have characteristics that fully correspond to those of a new material. Safety and quality of the vehicle must not be victims of recycling.

The so-called problematic and hazardous materials, that can be dangerous to humans, environment or facilities during processing and application, must be avoided. If this is not possible, then they must be clearly marked and must be easily disassembled. Materials and elements like e.g. asbestos, lead, mercury and CFCs are marked as problematic and should be avoided because of endangering the environment or because of their toxicity. The European regulation on the recycling of cars has prohibited the application of lead $(\mathrm{Pb})$, mercury $(\mathrm{Hg})$, cadmium $(\mathrm{Cd})$ and 6-valent chrome (CrVI) in cars since January 1st, 2005. Some exceptions are allowed.

Since 2007, the European policy on chemicals, REACH (Registration, Evaluation and Accreditation of Chemicals), has been trying to bring more clarity to the risks of application of different chemicals in the production [7].

Since December 2008, all chemicals in the European Union must fulfil the requirements of the regulation on registration, labelling and packaging of materials and mixtures (CLP - Classification, Labelling and Packaging). In addition, the world policy GHS - Globally Harmonized System of Classification and Labelling of Chemicals must be taken into account. 
The desired effect of recycling is to reduce the consumption of raw materials and energy.

Specific energy, which is needed to produce some material, is divided into primary and secondary energy. Primary energy includes all of the consumed energy required to produce a new material from raw materials obtained from natural sources and for further processing, as well as all the energy spent in transport in the course of this processing. Secondary energy is the sum of all energies needed to obtain a material from recyclates with the same characteristics as a "new" material.

Specific primary and secondary energies for a number of materials that are used in the automotive industry are presented in Table 1.

Table 1. Primary and secondary energy for different materials

\begin{tabular}{|c|c|c|}
\hline & $\begin{array}{c}\text { Primary energy } \\
\mathrm{kJ} / \mathrm{kg}\end{array}$ & $\begin{array}{c}\text { Secondary energy } \\
\mathrm{kJ} / \mathrm{kg}\end{array}$ \\
\hline Steel & 40.000 & 18.100 \\
\hline Iron & 34.000 & 24.000 \\
\hline Aluminium & 190.000 & 26.700 \\
\hline Glass & 30.000 & 13.000 \\
\hline Lead & 41.100 & 8.000 \\
\hline Copper & 1000.000 & 45.000 \\
\hline Rubber & 67.600 & 43.600 \\
\hline Polypropylene & 74.300 & 42.300 \\
\hline Polyvinylchloride & 65.400 & 29.300 \\
\hline Polyester & 95.800 & 50.000 \\
\hline
\end{tabular}

Energy analysis of production of different materials indicates that, with the increased application of recycled materials, the substantial savings in energy consumption can be achieved [8].

Different impurities often make it difficult for recycled material to have the same characteristics as the "new" material. However, where it is technically possible, the recycled material should always have preference over the "new" material.

\section{PLASTIC MATERIALS}

Plastic materials (plastics) are playing an increasing role. Their good workability, use-value and, especially, their low weight, meet the requirements of the automotive industry. In modern cars, their share is more than $15 \%$ of the vehicle weight. Hundreds of different plastic materials are applied in modern cars. Selection of these materials plays a very important role in automotive design, taking also into account the recycling. From the very beginning, a proper selection of plastic materials for all parts of the car must be made and, at the same time, to use the fewest possible number of different plastics. 
The plastic parts should be, in principle, made of only one material. As it is not possible, then chemically distinct polymers should be carefully selected. Not all plastic materials are compatible with each other, Figure 6. Selection of compatible components from one group of materials can significantly simplify recycling of the plastic materials.

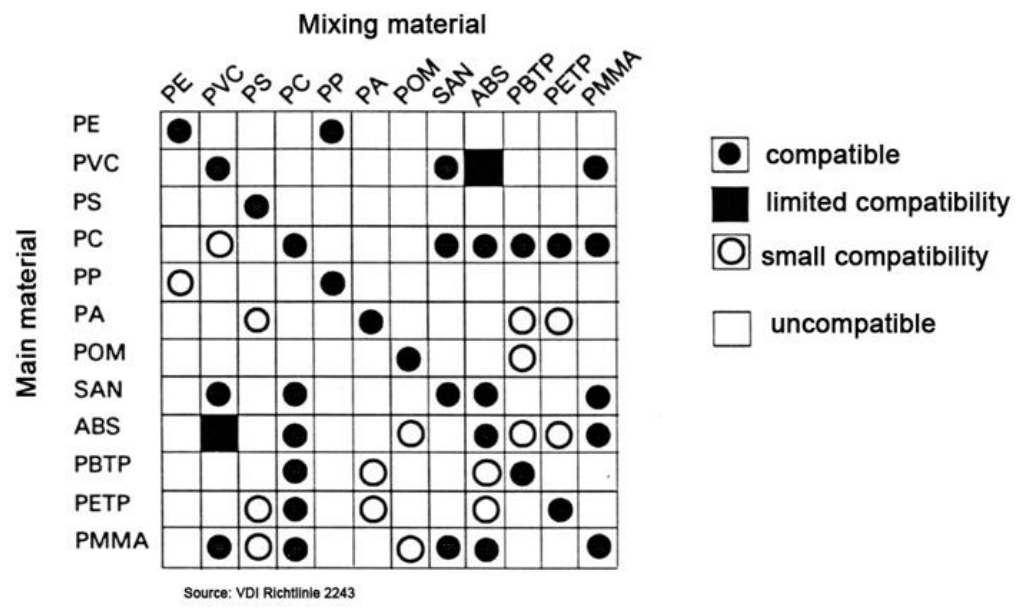

Figure 6. Compatibility between different plastic materials

Labelling has an important role in recycling plastics, allowing for their clean sorting and re-use at high technical level. In the European Union, a Directive 2000/53/EC on labelling of parts and materials is in effect. Also, ISO 1043, ISO 11469 and ISO 1629 norms, as well as VDA-260 and SAE-J 1344 policies are valid for labelling and identification of the parts of the vehicles whose weight exceeds $100 \mathrm{~g}$.

Since the mid-90's of the last century, the car and supporting industries have been developing concepts for the application of recyclates of plastic materials in the design of new vehicles [9]. In modern cars, the share of plastics from recyclates amounts between $10 \%$ and $15 \%$, Figure 7.

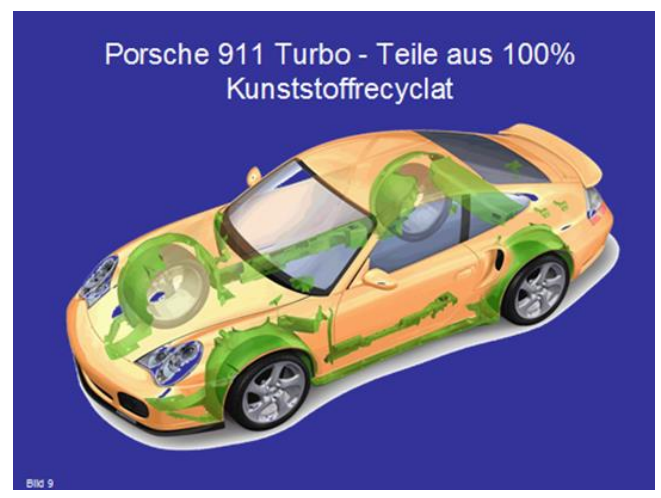

Figure 7. Plastic parts from recyclates in Porsche 911 Turbo 
The downside of composite materials used in design of cars - the inability of their material recycling, has reduced a great deal the original huge interest for these materials.

In addition to metals, plastics and glass, the automotive industry increasingly applies renewable resources, raw materials, from nature [10]. Beside leather for interior and rubber for the tyres, natural fibres from wood, cotton, jute, bamboo, flax, coconut, etc., gain more and more attractiveness for the automotive industry. Natural fibres, as high-quality materials, are often an alternative to plastic, synthetic fibres, Figure 8.

\section{Fibres used in automotive industry}

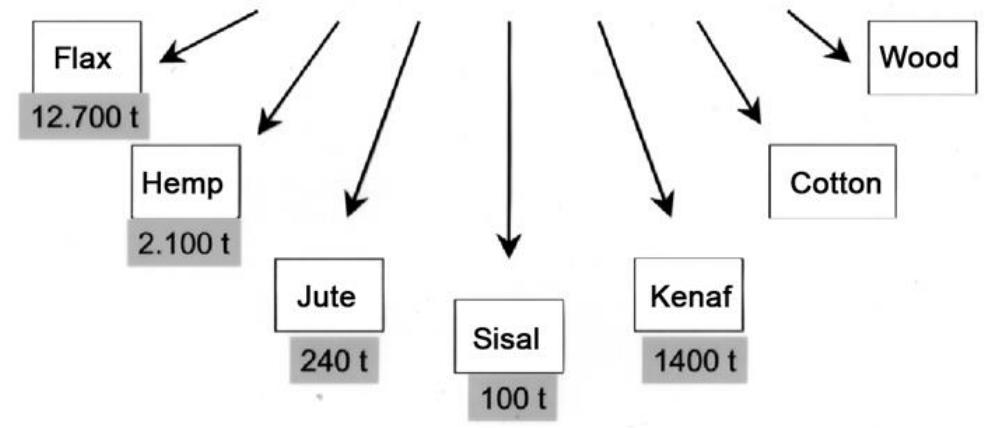

Figure 8. Renewable raw materials in car construction (Source: Audi)

Summarized, the automotive designers can be given the following recommendations for the selection of plastic materials:

- Make as many parts as possible of only one material.

- Construct the assemblies from chemically compatible materials.

- Provide ability for recycling and re-use of plastic materials

- Enable their re-use at as high technical level as possible.

- Label all parts according to the existing standards.

\section{DESIGN FOR DISASSEMBLING}

An important criterion for designing the recycling-ready vehicles is easy disassembling of the parts that should be further applied. The stipulated recycling quotas for old cars can only be achieved if separation of aggregates and assemblies and their clean sorting are enabled.

Automotive producers are obliged to prepare also manuals for vehicle disassembling for each vehicle. Criteria for assessment of disassembling are the time required for disassembling as well as weight and physical-chemical composition of disassembling parts. The time required for disassembling especially burdens the costs of the entire recycling process.

Known rules for the assembly of the vehicle cannot be applied without further notice to their disassembling. Disassembling of parts and material separation need to be as simple as possible and to be quickly implemented. 
Elements connecting the components and assemblies that can be re-used must enable disassembling without damage. This request is known as "manuals for reparation" goal in vehicle design.

With requests for recycling of other materials, the primary goal is to obtain as huge as possible quantities. Here, it does not matter whether the part is damaged or not. It is important to gain as much material in the shortest possible time, so that "violent" disassembly may be predicted.

A basic prerequisite for easy disassembly is easy access to the parts that are disassembled - without applying special tools. This includes the careful selection of technique of connecting the individual parts. Figure 9 shows the various connecting elements and their suitability for recycling.



Figure 9. Assessment of suitability of different connection elements for recycling

A bonding technique, which cannot easily be disassembled (like welding, gluing, riveting ...) should be avoided where possible. Instead, easily disassembled bonds should be applied (sockets, clips, bayonet-connections ...). For easy disassembling, deliberately weakened spots, designed to fracture, are also suitable.

Assemblies containing liquid working fluids must have suitable possibilities to drain the fluids. The "drying" of the vehicles is one of the first steps in vehicle recycling. The design must already take into account that the reservoirs of oil for engine, gearbox, differential and power steering are easy accessed and that they have the oil drain plug always at the lowest position.

The basic feature of recycling-ready design consists of selection of materials suitable for re-use and design suitable for disassembling.

To summarize, there are three available ways to meet regulatory standards and reduce the amount of waste, which occurs at exclusion of old cars from the traffic:

- design for recycling, 
- $\quad$ re-using as many parts as possible and recycling the rest of materials and

- $\quad$ energy use of car parts, which can't be used as materials.

These three ways are not mutually exclusive, but complement each other.

\section{PRODUCT'S LIFETIME}

It is generally valid, that twice-long product usage reduces the annual amount of waste by $50 \%$. Assemblies and spare parts need to be engineered and manufactured to have as long as possible lifetime, to be easily disassembled and, if it is technically possible, to continue to be used. The best preservation of product value, from the standpoint of saving of raw materials and energy is achieved by parts repair. Re-establishment of function and modernization of parts and assemblies are important elements of products recycling. In that way, savings of about $30 \%$ in materials and $40 \%$ in energy and reduction of time needed for production of about $140 \%$ are achieved in comparison with the creation of new product. product.

The price of generally repaired vehicle engine is about $40 \%$ less than that in a new

Only, even with prolongation of the time of use and with the application of recycled materials, the problem of removing old cars is not resolved, but only moved in time. This problem occurs again when the product made of recyclates finally does his part and definitely must be removed from traffic.

\section{LIFE CYCLE ASSESSMENT}

The total life cycle of a car encompasses its development, production, exploitation and, at the end of the lifetime, recycling of old vehicle. For a long time, this cycle was considered as a closed, circular system.

The comprehensive instrument for assessment of environmental impact of the product is the ecological balance or Life Cycle Assessment (LCA). All parts of the car are analysed with respect to the resulting consumption of raw materials and energy during their emergence, as well as to the resulting emissions and other environmental impacts in the course of the entire cycle of creation and use of the product - "from the cradle to the grave", Figure 10 [11]. 


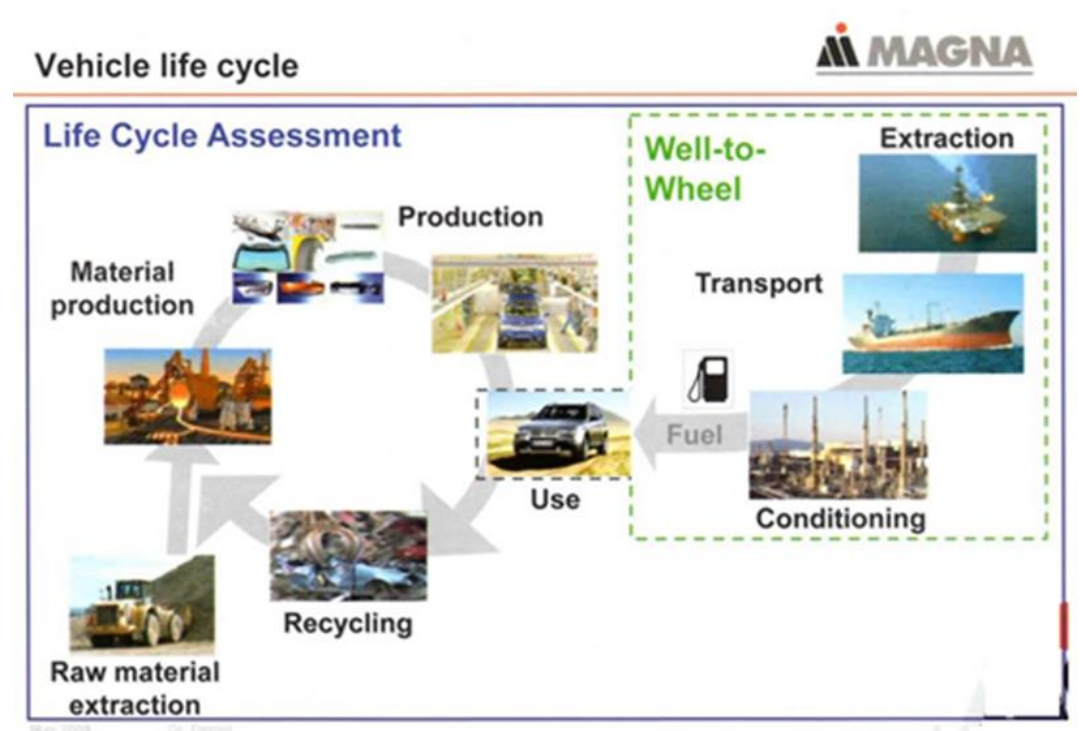

Figure 10. Life Cycle Assessment (,,from the cradle to the grave “)

According to the ISO 14040 series, Life Cycle Assessment is defined as "Systematic collection and analysis of inputs and outputs of material and energy into a system and related influences on the environment, which emerge in production and during functioning of the product in the course of its life cycle".

In addition to the ISO 14040, the European Commission has passed the guidelines for "environmental footprint" of products and production organizations in May 2013:

- $\quad$ Product Environmental Footprint - PEF and

- $\quad$ Product Environmental Footprint - PEF.

PEF and OEF methods rely on ISO 14040 series in their systematization of ecological balancing [12].

LCA contains an analysis of the product's entire life cycle, from the obtaining of raw materials for the construction of a new car, to different possibilities for use at the end of life: re-use, recycling, energy use (combustion) and the deposition of debris, including all phases of production, transportation, distribution, use and removal from traffic, Figure 11. 


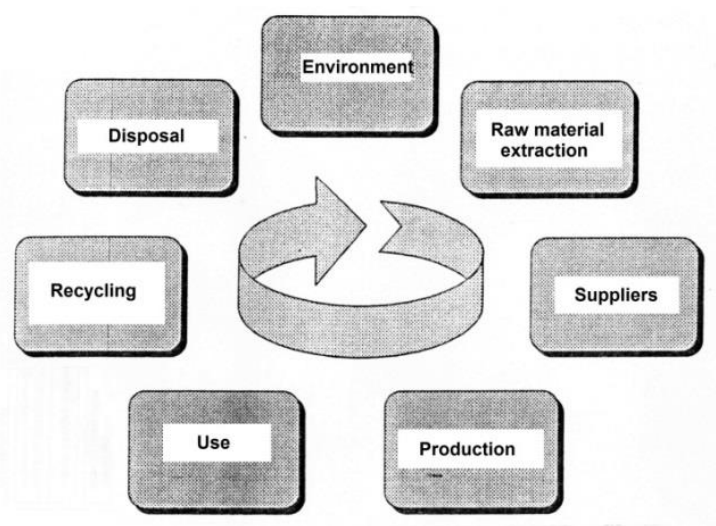

Figure 11. $L C A$ - circular cycle

With LCA, the automotive industry has an instrument, which primarily serves for internal optimization, and, through it, for reduction of negative environmental impact during the entire life cycle of the product.

Through ecological auditing, the existing situation in the consumption of materials, energy and creation of waste is compared to the legislation and the necessary activities for the reduction of threats to the environment are pointed out.

About $80 \%$ of environmental impact of the product is already predetermined in the development of cars. That is why it is very important, that the LCA and other environmental analyses are involved in development as soon as possible.

The concept of production, selected by the development department, bonds all other participants in the production. Therefore, already in product development, it must be well analysed which environmental impact will the planned production processes have or how the product can be withdrawn from traffic at the end of its use with no negative environmental impact.

The development department, therefore, has a crucial role in terms of environmental protection, because it predetermines subsequent environmental impact of both production processes and products.

In implementation of environmental balance (LCA), ISO 14040 predicts the following steps, Figure 12:

1. defining the objective

2. balancing the used materials and energy (inventory)

3. balancing the environmental impact and

4. assessment the conducted balancing.

The most interesting part in this scheme is the balancing of material and energy (Inventory). All flows of the applied materials and energy consumed are analysed there. 


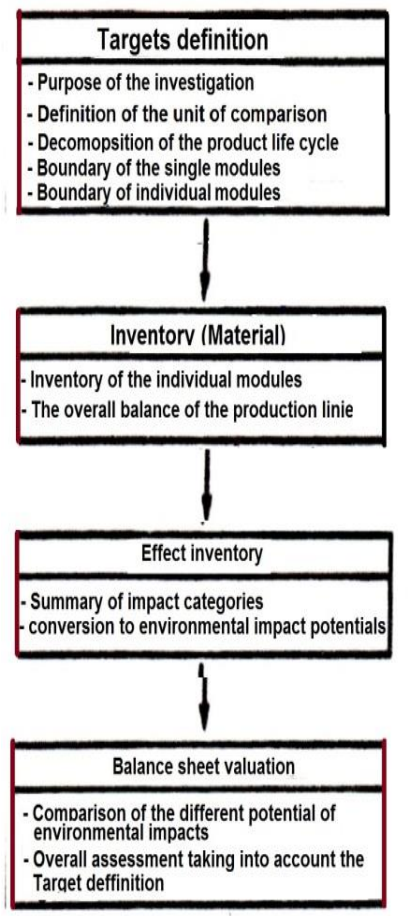

Figure 12. Process scheme in LCA (ISO 14040)

The results of this balancing are data regarding the consumption of materials, energy and emission of certain harmful components, Figures 13 and 14.

Primary energy needs for the life cycles

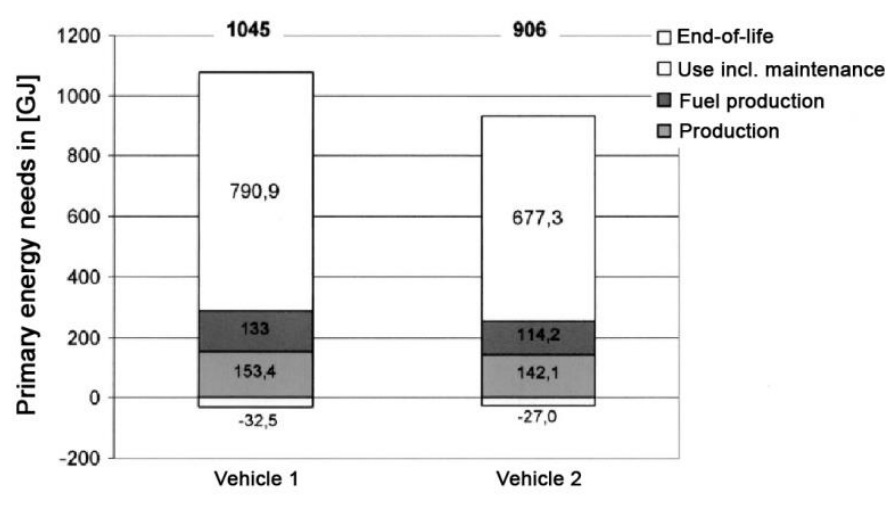

Figure 13. LCA - Energy consumption of two vehicles 


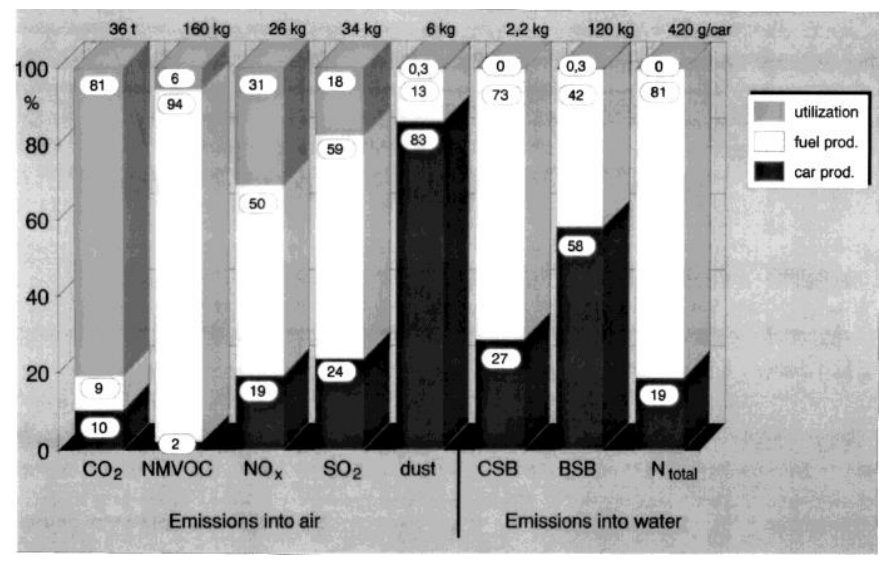

Figure 14. LCA - Emission of one vehicle (Source: VW)

A large number of parts in a single car $(15,000$ to 20,000$)$ make the ecological analysis of each part practically impossible. That is why the LCA is conducted mainly for five key components of the car, which together account for about $90 \%$ of the car weight.

Because the depth of production in automotive industry amounts from $30 \%$ to $40 \%$ of the car weight, the LCA is performed together with the supporting industry, for the most number o Ecological balance is today limited mainly to material balancing (Inventory). Analysis of environmental influence mostly is not done, because there is still not enough reliable data for evaluation of local and temporal impacts of different emissions on the environment.

The guidelines for so-called "Eco-Design" of the vehicles are derived from environmental balancing (LCA):

- designing, taking into account the environmentally clean production and use of vehicles (conservation of the reserves of raw materials and energy, reduction of waste quantities, minimization of energy consumption),

- designing, taking into account the reduction or replacement of hazardous, toxic or otherwise harmful substances from the production or when using cars,

- designing, taking into account the vehicle safety, ease of repair, durability and the ability to upgrade products and

- designing, taking into account the possibilities for re-use and recycling of products.

\section{CONCLUSIONS}

Modern society's efforts to reduce the negative impact of human activities on nature do not leave aside the end-of-use of the cars. In the European Union, a regulation on old cars was reached, which is mandatory for all Member States of the Union since 2002. Provisions of this regulation request that the re-use of materials must be taken into account already in the phase of designing the new vehicle and they also contain instructions about exploiting the old cars. 
The objectives of the European Union can be achieved only if, already at the stage of definition and design of the vehicles, the requirements in terms of recycling are defined. About 20 to 25 years pass from the first definition of the concept, through the start of production, to the recycling of cars. In that period, car producers have to anticipate and take into account the technological development and the development of legal regulations at the time of recycling the cars.

When engineering a car, every part of the vehicle is analysed in terms of ecological criteria: "the possibility of re-use of material", "convenience for recycling" and "critical materials". Recycling of the cars is closely related to the number and type of applied materials and simplicity with which these materials can be identified and separated. The primary principle of "Design for recycling" is to use a closed cycle of materials. Additionally, the recycled material must fully correspond to the new material in all its properties. The safety and quality of the vehicle must not be victims of recycling.

The desired effect of recycling is saving raw materials and energy. Analysis of production of different materials shows that with the increasing application of recycled materials substantial savings in energy consumption and raw materials can be achieved.

In modern cars, the contribution of plastics in car weight is $15 \%$. Selection of these materials plays a very important role when engineering a car taking into account the recycling. Labelling the plastics allows its clean sorting and reusing on a grand scale.

An important criterion for design for recycling of vehicles is easy disassembly of the parts that should be re-used. Car producers are obliged to prepare manuals for disassembly for each vehicle.

The total life of the car encompasses its development, production, exploitation and, at the end of the useful life, the recycling of old vehicles. This system is viewed as a closed cycle. The comprehensive instrument for assessment of environmental impact of the product "from the cradle to the grave" is the ecological balance or Life Cycle Assessment.

\section{ACKNOWLEDGMENTS}

More than 40 years have passed since the first Symposium or Congress "Motor Vehicles \& Motors". I had the pleasure and honor to participate in almost all of these events, where I gladly came to give expert reports, but, above all, to meet good comrades and friends from Kragujevac. I thank all previous organizers on regular invitations, but most of all I thank professor Stevan Veinović, because, without his commitment, this, probably record, attendance would not have happened.

\section{REFERENCES}

[1] Gruden, D.: Umweltschutz in der Automobilindustrie, Vieweg+Taubner, Fachverlage GmbH, Wiesbaden, 2008.

[2] Mehr Recycling per Gesetz, Umwelt (D) 7-8/2012.

[3] Gädicke, W.: Zusammenarbeit mit Lieferanten im Rahmen einer umwelt-orientierten Fahrzeugentwicklung. Umweltwirtschaftsforum 8(2000)2.

[4] Recycling-oriented design, Adam-Opel, 2014.

[5] Reuter, M.A. van Schaik, A.: Design for Recycling of Cars, Conference Paper, Mumbai, India 2008.

[6] IMDS - International Material Data System, Hewlett-Packard GmbH, 2013. 
[7] REACH - Verrordnung, Umweltbundesamt, Dessau, 2015.

[8] Materialrecycling schont Ressourcen und Umwelt, VDI-Nachrichten, 25/2010.

[9] Kunststoffrecycling wird zum wichtigen Wirtschaftsfaktor, VDI-Nachrichten, $42 / 2012$.

[10] Nachwachsende Rohstoffe im Automobilbau, BMW Group, 2002.

[11] Krinke, S. Boßdorf-Zimmer, B. U.a.: Ökobilanz Altfahrzeugrecycling. Volkswagen AG, 2005.

[12] Welche Spuren Produkte hinterlassen, Umwelt (CH) 3/2014.

[13] Europäisches Parlament stimmt der Novelle der Abfallrahmen-Richtlinie zu, Umwelt (D) $7-8 / 2012$. 